\title{
論文
}

\section{Numerical Analyses of Viscous Flow in a Wire Coating Die}

by

Kenichi FusE and Katsumi ORIMO

(Thc Furukawa Electric Co., Ltd., 6 Yawata-Kaigandori, Ichihara, Chiba 290)

\begin{abstract}
Numerical analyses of viscous flow in a wire coating die were made for non-Newtonian power-law fluids. The die was divided into three parts with different taper angles along the die axis, and a running wire was located on the axis.

The flow within each volume element was assumed to be the simple shear flow between parallel plates, but the boundary conditions for the total system were set as to fit for the actual geometry of the die. The velocity and stress distributions in the fluid and the tension exerted on the running wire were evaluated with varying combinations of the die geometry and the running speed of the wire. It was found that the shortening of the land length and the lowering of the reduction ratio were essential to realize the high speed coating. The results were supported by some model experiments for a high-molecularweight high-density polyethylene.
\end{abstract}

\section{電線被覆用ダイヘッド内における樹脂流動に関する数値解析}

\author{
布 施 憲一・折 茂 勝 己*
}

（原稿受理：1976年12月 1 日）

\section{1. 緒言}

電線絶縁被覆工程は，Fig. 1 亿示すよ5に，導体を送り出すサ プライ部, 予熱機, 更には絶縁被覆用の押出機, これに続く冷却 水槽扔よび引取機，巻取機により構成される。この被覆工程のラ イン線速は, 近年高速化が進み, 実験的には每分 $3,000 \mathrm{~m}$ にも迋 している11,2)。このよ5に，押出線速が高速化されるに伴い，成 型加工上極めて重要な幾つかの問題点が明らかになってきた。そ れは，(1)押し出された絶縁体の表面に発生する肌荒れ現象（外観 の悪化現象), (2) 絶縁押出工程で導体上飞働く張力 (Back Tension) の増大によって発生する導体径の細り現象である。これら の問題は, いずれも押出機本体に取り付けられたクロスヘッドダ イ内での樹脂流動と梁いかかわり合いを持つと考觉られ，高速成 形押出に適したダイヘッド部の開発が必要となる。しかしながら， ワイヤーのような移動物体が走行する電線被覆用のダイヘッド内

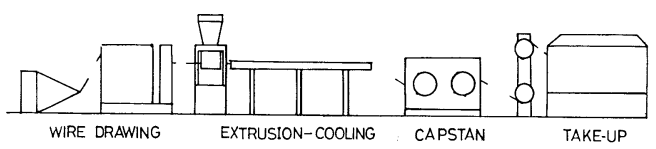

Fig. 1. Illustration of telephone wire insulation line.

* 古河電気工業株式会社通信研究部 千葉県市原市八幡海岸通 6 番地
に招ける樹脂の流動に関する基礎的な研究は十分に成されて招ら ず，その手法も十分には確立されていない。また，これまでに幾 つかの数値解析方法も提示されてはいるが, 実際に製造現場で俨 価検討が可能な解析㳎の誘導は成されては拉らず，実用性に久け ると考えられる，本報に招いては，高速絶縁押出に適したダイへ ッド部の形状寸法の探索, ならびに絶縁被覆押出に扣ける成形加 工性と樹脂流動との関連性を明らかにするための一段階として, 製造現場で評価測定が可能な実用的なパラメーターによるダイへ ッド内の流れに関する表示式（特に，肌荒れ現象の発生，ならび にダイス内を通過するワイヤー上に働く張力の登生に効する推定 を行うための速度分布, 張力に関する記述式) の誘導を行うこと を検討した。

\section{2. 解 析}

\section{$2 \cdot 1$ 絶縁被覆押出}

絶縁被覆押出に括いて, 押出機本体よりクロスヘッド部へ送り 込まれて来た樹脂は, Fig. 2 亿示すよ5に, クロスヘッド内でそ の流れの方向を $90^{\circ}$ 変更し, ワイヤーをダイ流路部へと導き入れ るニップル部外周面流路を経てダイス部へ流入し，ワイヤ一上に 被覆される，ここでは，流路をその流れを起こさせる駆動力の相 違により, 次の二つの領域に分けて解析を行った. 


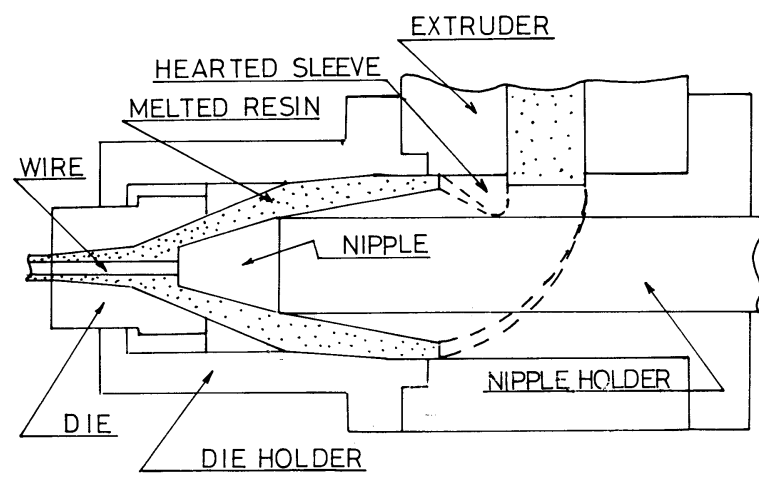

Fig. 2. Schematic representation of wire coating crosshead and die.

（i） Die〜Nipple 間隙内流路（流孔は，圧力流を成すむのと する)

（ii） Die〜Wire 間隙内流路（圧力流と率引流の複合流が考え られる)

この二つの流路は, 実際には連続流路であるため, 個々の流路を 流れる流体は互いに影響し合って流れていると考兄られるが，こ こでは解析を簡単にするため, 流れを独立流路内の流れとして取 り报 う。ところで, 前述のように, クロスヘッド部に流入し，そ の方向を $90^{\circ}$ 変更した後の流れに扣いては, 押出機側に位置した 短い樹脂流路を通って流れて来たものと, それと反対側の長い流 路を通って来たものとでは, 同一断面, 同一半径上に拈ける流れ の速度が異なっていることが予想される。このため, 実際の電線 被覆用のクロスヘッドに招いては，このような流れに拉ける不均 一さを軽滅するため，クロスヘッド内に八ート状スリーブとかウ エッジリングと称するアダプターを設け, 流れの均一化をはかっ ているが，その効果については確認されてはいない，本解析に拉 いては，このような不均一流動によって誘起される半径方向への 流れが，流れ力向のそれと比べて流れ全体に及ぼす影響が小さい とし, 解析を簡単にするため前記二つの流路部に拈ける流れは, 均一流れを成すものとして解析を行った。

\section{$2 \cdot 2$ 既往の研究}

Wire-Coating に拈けるクロスヘッドダイ内の流れに関する厳 密解を得ることは，はなはだ困難である，とれは，ダイ内の流れ が未だ十分な解析解が得られていない非ニュートン流体の円錐管 内流れであるに加えて ${ }^{3)}$, 移動物体すなわちワイヤーの存在が問 題を更に一層複雑にしているためである。 それ故, wire-coating 用のクロスヘッドダイ内を流れる樹脂の流動に関する厳密解を得 ようとする試みは, 著者の知る限りでは全く行われていない。 た，近似解を得ようとする試みも幾つか成されてはいるが，簡便 でかつ実用的な関係式の誘導は十分には達成されていない4) すなわち, これら近似解を得ようとする既往の研究4),5) と扣いて は，流れ方向に微細等分割した微小流路内の流れを二重円筒管内 の流れと仮定し、円筒座標系を用いてこの問題をとらえようとし ている.この場合, 式(1)に示すように，

$$
\frac{d V}{d r}=\left\{\frac{1}{2 K}\left[\left(\frac{\partial P}{\partial z}\right) r+\frac{c}{r}\right]\right\}^{\frac{1}{n}}
$$

$(V$ : 流速, $r$ :半径, $\partial P / \partial z$ :流れ方向への圧力勾配, $K, n:$ ヘ き指数流体の物質パラメーター, $c$ : 定数)
運動方程式が複雑で数学的煩雑さを伴い, 解析過程に括いて実際 には測定が困難なパラメーターである压力勾配 $(\partial P / \partial z)$ を既知 関数として与えたり, 更にニュートン流体として取り报うなど, 非実用的な解析例が多い，したがって，ここではクロスヘッド内 の流れを類推するための関係式を設定する際に，現場での評価測 定が可能なこと，更に簡便で実用的であることの二つの要因が重 要であると考光, 実用的なパラメーターによる流れの表示式を誘 導するため，以下のモデルを用いた。

\section{$2 \cdot 3$ 仮 定}

(1) Die〜Nipple 間隙部内の流れは，実際は非平行な同心テー パー管内の流机である。 しかし，Fig. 3 に示すように，流れ方向 に微細等分割した微小区間に拈いては, ダイス部のテーパー角 扣よびととニップル部のテーパー解 $\beta$ との差による流れへの影響 が無視できると考えられること．更には Die〜Nipple 間隙部の 間吵深さ $H_{c}$ の曲率半径 $r_{c}$ に効する比 $H_{c} / r_{c}$ が 0.2 前捘である ことより，流路端部の流れへの影響が無視できると考え，流れを 二枚の平行平板間の流れと仮定する. (2) Die〜Wire 間隙部に対 しては，流れ軸と $\alpha$ だけ傾いた板と流れ軸に平行でかつ速度 $V_{0}$ で移動するもら一枚の板で囲まれた平板間内の流れとし，先例同 様流れ方向微細等分化した区間に刘しては，ダイス壁面のテー パー角 $\alpha$ の流れへの影響が小さく，かつ $H_{c} / r_{c}$ 比が0.2〜0.5であ ることから，この流路に刘しても流路端の影響が無視できるとし て，流れを二枚の平行平板間の流れと仮定する。(3) 流れは等温, 非圧縮性でかつ定常流動を成すものとする．(4)流体働く重力 等の体積力は無視する。（5）流れに抒いては管壁面上およびワイ ヤー上での流体の「滑り」はないものとする. (6) ダイ, ニップ ル，ワイヤー三者の心軸は同一線上飞あるものとし， 2・1 項に 記述したように，流れは軸刘称の均一流れを成するのとする。

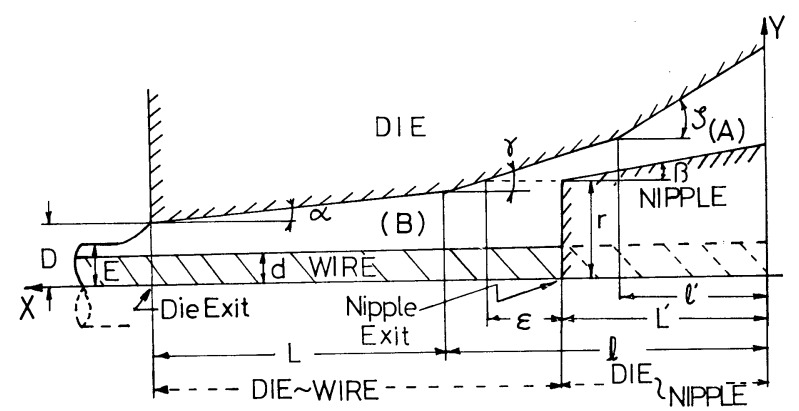

Fig. 3. Cross section of wire coating die, consisting of two convergent channels; (A) clearance between die and nipple, and (B) cleararce between die and wire. Die consists of three tapered parts, having angles of $2 \alpha, 2 \gamma$, and $2 \zeta$ each. Taper angle of nipple is $2 \beta$. $\varepsilon$ indicates gam space. $d, D$ and $E$ are radii of wire, die exit, and coated core, respectively.

\section{$2 \cdot 4$ 運動方程式}

Fig. 3 に示したクロスヘッドダイ内の流路を前記仮定により， Fig. 4 亿示すような二枚の平板間内流路とし， $x y z$ 直角座標系を 図のように導入する。（ただし，Die〜Nipple 間隙部内の流れに 対しては, Nipple 壁面に沼って一あるいは平行に一 $x$ 軸を取る のが一般的であるが，本解析に执いては，流れに関し Die〜Wire 


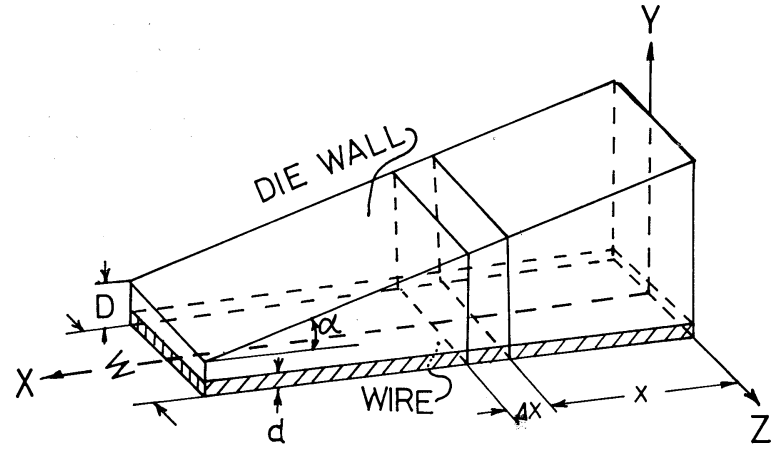

Fig. 4. Idealized slit channel. Within a narrow section of width $\Delta x$, the die wall and the wire surface are both assumed to be flat and parallel with each other. Coordinate $X$ is in the running direction of wire.

間隙部入口付近と Die〜Nipple 間隙部出口付近の相刘的関係を Fig. 3 に示したような形で評価することが可能なように，便宜上， $x$ 軸をDie〜Wire 間隙部の場合と同様に，ワイヤー上に $x$ 軸を 取ることとする.）この時，流れ方向に微細等分化した微小区間 は，二枚の平行平板とみなされ，流れ方向に直角な $y, z$ 両方向 への速度成分は， $x$ 方向の速度成分に比べて非常に小さいとみな せる．更に流れ方向の速度成分が $z$ 座標と独立であるとすれば， 速度 $V$ は,

$$
V_{x}=V(x, y), \quad V_{y}=V_{z}=0
$$

と表すことができる。 また，良く知られた運動方程式の $x$ 成分， 並びに連続の式はそれぞれ式 (3) 执よび(4)のよ5に表される.

$$
\begin{aligned}
& \rho\left(\frac{D V_{x}}{D t}\right)=-\left(\frac{\partial P}{\partial x}\right)+\left(\frac{\partial \tau_{x x}}{\partial x}+\frac{\partial \tau_{y_{x}}}{\partial y}+\frac{\partial \tau_{z x}}{\partial z}\right)+\rho g_{x} \\
& \frac{D \rho}{D t}+\rho\left(\frac{\partial V_{x}}{\partial x}+\frac{\partial V_{y}}{\partial y}+\frac{\partial V_{z}}{\partial z}\right)=0
\end{aligned}
$$

ただし， ○は密度， $\frac{D}{D t}$ は実質微分係数， $\partial P / \partial x$ は流れ方向への 圧力勾配, また, $\tau_{x x}, \tau_{y x}, \tau_{z x}$ は応力成分, $g_{x}$ は体積力の $x$ 成分 を表す。ここに，前述の仮定より， $\rho=$ const., $g_{x}=0, \frac{D V_{x}}{D t}, \frac{D \rho}{D t}$ $=0$. 更に, (2), (4) 両式上り応力成分に関して, $\partial \tau_{x x} / \partial x=0$, $\partial \tau_{z x} / \partial z=0$. また，流体が「べき指数流体」であると仮定すれば， $K$ 扣よび $n$ を非ニュートン流体の物質パラメーターとして,

$$
\tau_{x y}=K\left|\frac{\partial V_{x}}{\partial y}\right|^{n-1} \frac{\partial V_{x}}{\partial y}
$$

と表されるから, 結局, 式(3)の運動方程式は, 次のよ5に与えら れる。

$$
-\left(\frac{\partial P}{\partial x}\right)+\frac{\hat{o}\left[K\left|\frac{\partial V_{x}}{\partial y}\right|^{n-1} \frac{\partial V_{x}}{\partial y}\right]}{\partial y}=0
$$

ここで，㭱力勾配 $(\partial P / \partial x)$ が $y$ 座標とは無関係であると仮定し， 上式をyで二回積分すれば，次の関係式を得る.

$$
V_{x}=\frac{n}{n+1}\left[\frac{1}{K}\left|\frac{d P}{d x}\right|\right]^{\frac{1}{n}} y^{\frac{n+1}{n}}+C_{1} y+C_{2}
$$

ここに, $C_{1}, C_{2}$ は積分定数である.

2・5 Die〜Nipple 間隙内の流れ

式 (7) に対する境界条件は, Fig. 5 に示すように，y=h $h_{1}$ 打よ

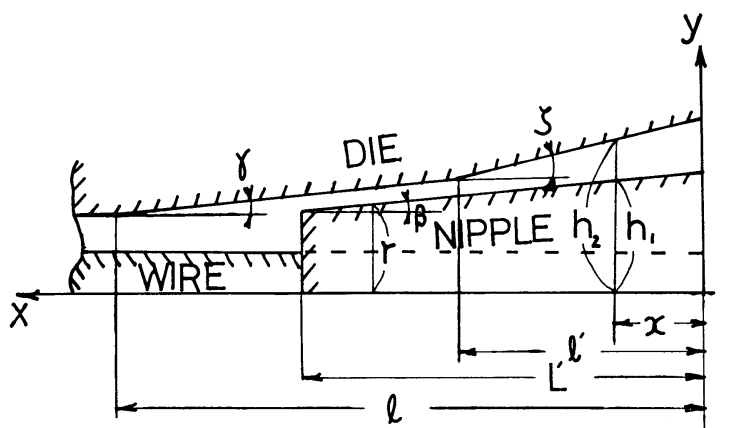

(A) DIE NIPPLE

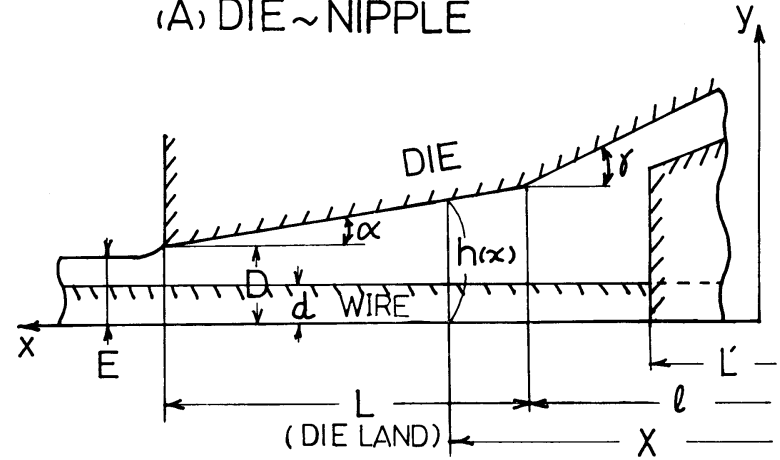

(B) DIE WIRE

Fig. 5. Geometry of convergent narrow channel of die heads.

び $y=h_{2}$ で $V_{x}=0$ である.この時, 式 (7)は

$$
\begin{aligned}
& V_{x}=\frac{n}{(n+1)\left(h_{2}-h_{1}\right)}\left[\frac{1}{K}\left|\frac{d P}{d x}\right|\right]^{\frac{1}{n}}\left[\left(h_{2}-h_{1}\right) y^{\frac{r+1}{n}}\right. \\
& \left.\quad+\left(h_{1}^{\frac{n+1}{n}}-{h_{2}}^{\frac{n+1}{n}}\right) y-h_{1} h_{2}\left(h_{1}{ }^{\frac{1}{n}}-h_{2}{ }^{\frac{1}{n}}\right)\right]
\end{aligned}
$$

ここで, $h_{1}, h_{2}$ は次の幾何学的関係を満足する.

(i) $0 \leqq x \leqq l^{\prime}$

$$
\begin{aligned}
& \left\{\begin{array}{l}
h_{1}=r+\left(L^{\prime}-x\right) \tan \beta \\
h_{2}=D+L \tan \alpha+\left(l-l^{\prime}\right) \tan \gamma+\left(l^{\prime}-x\right) \tan \varphi
\end{array}\right. \\
& l^{\prime}<x \leqq L^{\prime}
\end{aligned}
$$$$
\text { (ii) } l^{\prime}<x \leqq L^{\prime}
$$

いま， $L^{\prime}$ は実質的には意喍を持ため值であるため，これを実用 上重要な Die〜Nipple 間隔の長さ $\varepsilon$ で表すことにすると， $L^{\prime}$ は 次式

$$
L^{\prime}=l-\varepsilon-\frac{r-(D+L \tan \alpha)}{\tan \gamma}
$$

で与兄られる。 また, 式 (8)に扔いて, 压力勾配 $(d P / d x)$ は実際 上測定不可能な值であり，これを測定可能なパラィーターに変換 しなければならない。ここで, Fig. 4 亿示された流路において, 流路幅 $W$ を一定とすれば，単位幅当たりの吐出量 $Q / W$ は,

$$
\frac{Q}{W}=\int_{y_{1}}^{y_{2}} V_{x} d y
$$

更に, Fig. 3 より明らかなよ5に, $Q / W$ は絶縁体半径を $E$, 導 体の半径を $d$ ，ワイヤーの速度を $V_{0}$ とすれば，次式で与えられ る.

$$
Q / W=\left(\rho / \rho_{m}\right)(E-d) V_{0}
$$

ただし， $\rho_{m}$ は温度 $T^{\circ} \mathrm{C}$ での溶融樹脂の密度で，ここでは次式で 
与えられる経験式を用いた。

$$
\rho_{m}=\left[1.2566+0.936(T-120) \times 10^{-3}\right]^{-1}
$$

したがって，式(14)，(15)の関係を式(8)に代入すれば，Die〜Nipple 間隙部に扣ける流速 $V_{x}$ は，次式で与えられる。

$$
V_{x}=\frac{(2 n+1)\left[\left(\frac{\rho}{\rho_{m}}\right) V_{0}(E-d)\right]\left[\left(h_{2}-h_{1}\right) y^{\frac{n+1}{n}}+\left(h_{1}^{\frac{n+1}{n}}-h_{2}^{\frac{n+1}{n}}\right) y\right.}{\left(h_{2}-h_{1}\right)\left[\left(h_{1}-h_{2}\right)\left({h_{1}}^{\frac{n+1}{n}}+h_{2}^{\frac{n+1}{n}}\right)+2 n h_{1} h_{2}\left({h_{1}}^{\frac{1}{n}}-{h_{2}}^{\frac{1}{n}}\right)\right]}
$$

また，ずり速度 $\dot{\gamma}_{N}$ は， $\dot{\gamma}_{N}=\partial V_{x} / \partial y$ より与えられるから，式 (17) の結果より, 次のように表される。

$$
\dot{\gamma}_{N}=\frac{(2 n+1)\left[\left(\frac{\rho}{\rho_{m}}\right) V_{0}(E-d)\right]\left[\frac{n+1}{n}\left(h_{2}-h_{1}\right) y^{\frac{1}{n}}+h_{1}^{\frac{n+1}{n}}-h_{2}^{\frac{n+1}{n}}\right]}{\left(h_{2}-h_{1}\right)\left[\left(h_{1}-h_{2}\right)\left(h_{1}^{\frac{n+1}{n}}+h_{2}^{\frac{n+1}{n}}\right)+2 n h_{1} h_{2}\left({h_{1}}^{\frac{1}{n}}-h_{2}^{\frac{1}{n}}\right)\right]}
$$

更に, ずり応力 $\tau_{x y}$ は, 式(18)で求められたずり速度と, 実験によ って求められる非ニュートン流体の物質パラメーター $K$ とから, 式 (5)により訃算することが可能である.

\section{2・6 Die〜Wire 間隙内の流れ}

Fig. 5 飞示された流路に対し，境界条件は次のと招りである.

$$
\begin{cases}y=h(x) & \text { で } V_{x}=0 \\ y=d & \text { で } V_{x}=V_{0}\end{cases}
$$

ここで, $h(x)$ は Fig. 5 より次の条件を満足する.

(iii) $L^{\prime}<x \leqq l$

$$
h(x)=D+L \tan \alpha+(l-x) \tan \gamma
$$

(iv) $l<x \leqq l+L$

$$
h(x)=D+(l-L-x) \tan \alpha
$$

この時, 式 (7) は次のように表される.

$$
\begin{aligned}
V_{x}=\frac{n}{n+1} & {\left[\frac{1}{K}\left|\frac{d P}{d x}\right|\right]^{\frac{1}{n}}\left[y^{\frac{n+1}{n}}-h^{\frac{n+1}{n}}+(y-h)\left(y^{\frac{n+1}{n}}-d^{\frac{n+1}{n}}\right)(d-h)\right] } \\
& +\frac{y-h}{d-h} V_{0}
\end{aligned}
$$

ところで，(14)，(15) 両式より

$$
\frac{n}{n+1}\left[\frac{1}{K}\left|\frac{d P}{d x}\right|\right]^{\frac{1}{n}}=\frac{(2 n+1)\left[V_{0}(h-d)-\frac{Q}{W}\right]}{h^{\frac{2 n+1}{n}}-d^{\frac{2 n+1}{n}}-(2 n+1) d h\left(h^{\frac{1}{n}}-d^{\frac{1}{n}}\right)}
$$

更に，棓算を簡単にするため， $\lambda=y / h, \psi=h / d$ なる無次元量を 導入すれば，式(21)の $V_{x}$ は次のように表される。

$$
V_{x}=\frac{\psi}{1-\psi}\left\{F\left(\lambda^{\frac{n+1}{n}}-1\right) \psi^{\frac{1}{n}}(1-\psi)+\left[1+F\left(\psi^{\frac{n+1}{n}}-1\right)\right](\lambda-1)\right\}
$$

ここに, Fは次式を満足する無次元量である。

$$
F=\frac{(2 n+1)\left[\psi-1-\frac{\rho}{\rho_{m}}\left(\frac{E}{d}-1\right)\right]}{\psi^{\frac{2 n+1}{n}}-1-(2 n+1) \psi\left(\psi^{\frac{1}{n}}-1\right)}
$$

また，式(23)よりずり速度 $\dot{\gamma}_{\mathrm{D}}$ は，次式で与兄られる。

$$
\dot{\gamma}_{\mathrm{D}}=\left[\left(\frac{n+1}{n}\right) F(\psi \lambda)^{\frac{1}{n}}+\frac{1+F\left(\psi^{\frac{n+1}{n}}-1\right)}{1-\psi}\right] \cdot \frac{V_{0}}{d}
$$

更に，ずり応力は(5), (25)両式より求められる.

\section{2・7 クロスヘッド内で発生する張力}

クロスヘッドのダイス部を走行するワイヤーに発生する張力は, ワイヤーの速度と樹脂の流速との相対的な関係によって決定され る.すなわち，ワイヤーの移動速度がそこを流れる流体の速度よ りも大きい場合には，明らかに樹脂の流れがワイヤーの走行を妨 げることになり，ワイヤーをその長手方向に引き延ばそうとする 張力がワイヤー上に働くことになる。このような張力 (Back Tension）は，クロスヘッド部以外飞も，絶縁工程の冷却水槽中， 扣よび引取機，巻取機においても発生するが，それらはダイヘッ ド部で発生する張力の約半分以下と小さい，乙かしながら，ライ ン全体としての張力を軽減することが必要で，水槽をはじめとし て, ラインの構成要因の検討も現在進められている。ところで, このダイス部で発生する張力を求めるには，まず第一にワイヤー 上に働くずり応力を求める必要がある。ここで，先の解析より， ダイス内を移動するワイヤー上でのずり速度 $\dot{\gamma}_{\mathrm{w}}$ は, 式(25)に招い $\tau, \psi \lambda=1$ ょり,

$$
\dot{\gamma}_{\mathrm{w}}=\left[\left(\frac{n+1}{n}\right) F+\frac{1+F\left(\psi^{\frac{n+1}{n}}-1\right)}{1-\psi}\right] \frac{V_{0}}{d}
$$

で与えられる。したがって，(5)，(26)兩式により，ワイヤー上に働 くずり応力 $\tau_{\mathrm{W}}$ は， $\tau_{\mathrm{W}}=K\left|\dot{\gamma}_{\mathrm{w}}\right|^{n-1} \dot{\gamma}_{\mathrm{W}}$ で計算することができる. ところで, ワイヤーの長手方向に微細等分化された微小要素 $\Delta x$ 上に働く力のつりあいを奨えると, 要素内のワイヤー表面に括け るずり応力を $\tau_{\mathrm{wr}}$, そこに発生する張力を $\Delta T$ とすれば, 次の関 係を満足する。

$$
\Delta T=-2 \pi d \cdot \Delta x \tau \mathrm{wr}
$$

ここで，ダイス内を通過するワイヤーの全長は, Fig. 5 より $L+$ $l-L^{\prime}$, 更に流路の刻み幅を $m$ とすれば, $\Delta x=\left(L+l-L^{\prime}\right) / m$ より, ダイス内の $i$ 番目の微小区間に执ける張力の增分 $\Delta T_{i}$ は, 次式 で与えられる。

$$
\Delta T_{i}=K \cdot 2 \pi d^{1-n} \cdot\left(\frac{L+l-L^{\prime}}{m}\right) \cdot\left[\left(\frac{n+1}{n}\right) F+\frac{1+F\left(\psi^{\frac{n+1}{n}}-1\right)}{1-\psi}\right]^{n} \cdot V_{0}{ }^{n}
$$

(28)

また,クロスヘッド全体にわたって発生する張力 $T$ は, $T=\sum_{i}^{N} \Delta T_{i}$ より誩算される。

\section{3. 計 算 例}

これまでの解析により導かれた関係式を用いて行った計算例を 以下に示す。計算は，単純な技術訃算であるため，卓上型計算機 でも可能であるが，時間の都合上，今回は FACOM 230-58 を用 いた。刻及幅は，計算䛊差を確認したうえで $0.05 \mathrm{~cm}$ とした。 と ころで, 計算を行うにあたって必要となる樹脂の溶融粘度 $K$ は, ずり速度が $10^{4} \mathrm{sec}^{-1}$ 以上飞対しても測定が可能な特別な Capillary Rheometer を通常の押出機の先端部に取り付けて測定した。得 られたデーターをもとに，最小自乘法によりその流動曲線を決定 して，演算に用いた．Fig. 6 に流動曲線の一例を，また Table 1 に訪算例として用いたダイ、ニップルの帅状，並びに操作条件を 


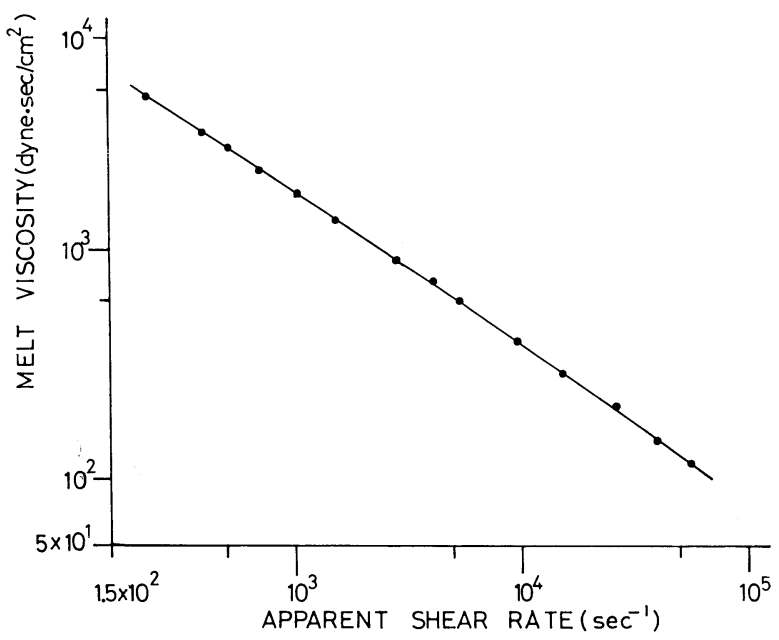

Fig. 6. Flow curve of high density polyethylene for wire insulation (MI $0.4 \mathrm{~g} / 10 \mathrm{~min}$., density $0.945 \mathrm{~g} / \mathrm{cm}^{3}$ ) at $250^{\circ} \mathrm{C}$. Measurements were made with a capillary rheometer having length-to-diameter ratio of 30 , and diameter of $1.00 \mathrm{~mm}$.

Table 1. Geometric parameters of wire coating die.

\begin{tabular}{|c|c|c|c|}
\hline & APPELLATION & KEY & VALUE \\
\hline & EXIT RADIUS & $D$ & $0.035 \mathrm{~cm}$ \\
\hline & LAND LENGTH & $L$ & $1.000 \mathrm{~cm}$ \\
\hline & 2nd TAPER LENGTH & $l-l^{\prime}$ & $0.650 \mathrm{~cm}$ \\
\hline 贸 & 3rd TAPER LENGTH & $l^{\prime}$ & $0.700 \mathrm{~cm}$ \\
\hline & LAND TAP. SEMI ANGLE & $\alpha$ & $3.0^{\circ}$ \\
\hline & 2nd TAP. SEMI ANGLE & $r$ & $20.0^{\circ}$ \\
\hline & 3rd TAP. SEMI ANGLE & $\zeta$ & $30.1^{\circ}$ \\
\hline 된 & EXIT RADIUS & $\gamma$ & $0.100 \mathrm{~cm}$ \\
\hline 合 & TAPER SEMI ANGLE & $\beta$ & $20.0^{\circ}$ \\
\hline & RE RADIUS & $d$ & $0.020 \mathrm{~cm}$ \\
\hline & ULATION RADIUS & $E$ & $0.033 \mathrm{~cm}$ \\
\hline & POWER LAW INDEX & $n$ & 0.4 \\
\hline $\bar{n}$ & DENSITY & $\rho$ & $0.945 \mathrm{~g} / \mathrm{cm}^{3}$ \\
\hline & MATERIAL TEMP. & $T$ & $250^{\circ} \mathrm{C}$ \\
\hline & N NIPPLE CLEARANCE & $\varepsilon$ & $0.200 \mathrm{~cm}$ \\
\hline & RE VELOCITY & $V_{0}$ & $1,000 \mathrm{~m} / \mathrm{min}$ \\
\hline
\end{tabular}

示す. 対象材料は, $M I=0.4(\mathrm{~g} / 10 \mathrm{~min})$, density $=0.945 \mathrm{~g} / \mathrm{cm}^{3}$ の通信絶縁用の高密度ポリエチレンである.

\section{4. 考察}

\section{4 ・1 クロスヘッドダイ内における速度分布}

Fig. 7 に, Table 1 に記したクロスヘッドダイの Die〜Nipple 間隙部内に括ける速度分布，並びに Fig. 8 亿 Die〜Wire 間隙部 内の速度分布の計算結果を示した。 まず第一に, Die〜Nipple 間

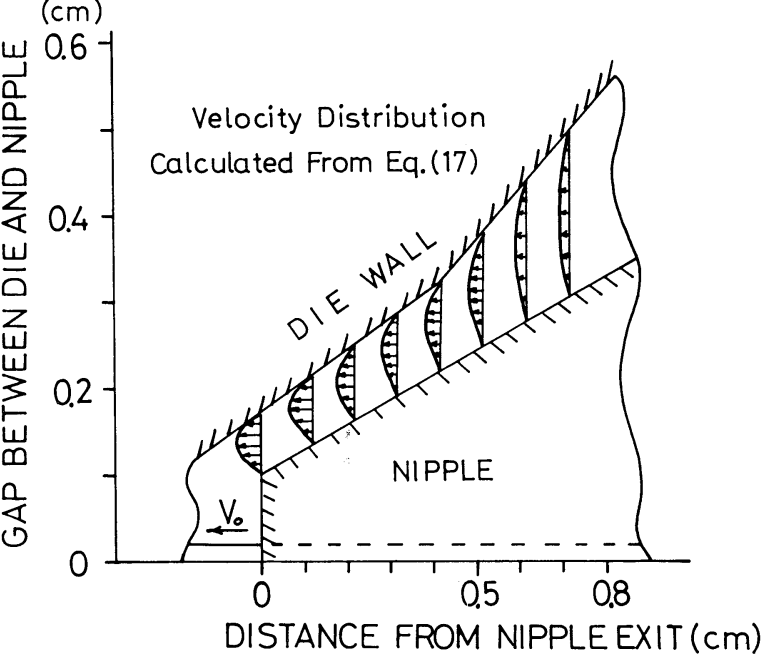

Fig. 7. Axial velocity profiles in convergent channel between die and nipple, calculated from eq. (17) at $V_{0}=1,000 \mathrm{~m} / \mathrm{min}$.

隙部内の流れに関する計算結果は，ダイス扣よびニップル両部の 寸法形状を実用範囲内で変化させても大きく変化せず，興味ある 結果は得られなかった。この結果は，我々がこれまで行ってきた 押出実験に扔いて，これら Die〜Nipple 間隙部の寸法形状が押 出特性（例㓪ば，押出物外観の荒れ，導体径の細りなど）には大 きく影響しないことからすれば，むしろ妥当な結果であると思わ れる。しかしながら，本解析に抢いては，Die〜Nipple 間隙部内 の流れを Die〜Wire 間隙部の流れと切り離し，独立流路として 取り扱い，更にはクロスヘッド部で流れの方向が $90^{\circ}$ 変更される ことにより，発生する不均一流動を無視し，流れを均一な一様流 れと仮定して取り扱った．押出特性に及ぼすこれらの影響は，例 えば導体と絶縁体との偏心問題には重要であり，今後検討されね ばならぬ課題である。次に，いま一つの流路である Die〜Wire 間隙部の流れに関する計算結果は重要である．Fig. 8 にその結果 の一例を示したように, Nipple 部出口付近と Die 出口部付近の 流れとでは，その様相を異にして扣り， Nipple 出口部付近に導 体の進行方向と逆向きの流れが認められた。 この Die〜Wire 間 吵内の流れは，押出機本体とダイス出口部との流路間に発生した 圧力差による流れ (圧力流) と，導体がダイス内を走行すること によって発生する率引流とによって構成されていると考えられる

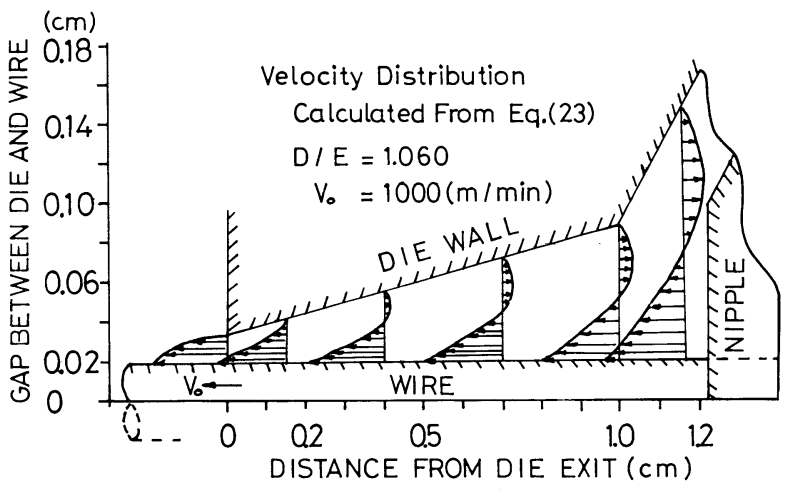

Fig. 8. Calculated axial velocity profiles in 3.deg. convergent channel between die and wire. 
が，この種の流れには，押出機に設けられたスクリュ一内の流れ がある。このスクリュ一内の流れに招いては，ある条件下で流体 に背圧がかかることにより，流路内に逆流が発生する。これょり 類推すれば, この Die〜Wire 間隙内に招いても, 流れの一部に 背圧がかかる場合には, 計算結果のように逆流の発生は可能とな る.また，二重円筒管流れとして解析を行った Fenner ${ }^{5)} ら も ，$ この逆流の存在を示唆している. しかしながら, 電線被覆用のク ロスヘッド内の流れを実験的に確認することは, 現用のダイヘッ ドの機構から考えて, かなり困難である. 例えば, 流れに沿った 圧力分布の測定が可能な機構を考虑する必要があり, 現時点でこ の逆流の有無を確認することは不可能である。また, 本解析では, 円錐管流れを 2 枚の平行平板間の流れとしたが, Nipple 出口部 付近に括ける前記 $H_{c} / r_{c}$ の比が Die 出口部付近の 0.2 に比べ, 0.5 と非常に大きいことより, この Nipple 出口部付近の流れに 刘し，スリット流れを適用することにより発生する誤差は, 大さ くなることが予想される。したがって, 本解析法によって得られ た関係式の適用範囲は, 厳密には Die 出口部付近に限定される と考えるべきであり，ここに計算された逆流の存在，並びに有意 性についてこれ以上言及することは無理であるう。しかしなが ら，これまでの押出実験によれば，絶縁線の押出特性が，Die と Nipple の相対位置関係を決定する $\varepsilon$ に大きく影響されることよ り, Nipple 出口部付近の流れのプロフィールはかなり重要であ り，今後更に一層梁い検討解析が必要である。次に，ダイス出口 部付近の流れに関する計算結果は，ダイス部の寸法形状に大きく 依存する傾向を示した，すなわち，ニップル出口部よりダイス出 口部に至るダイランド部の流れに执いては，特にダイス出口部付 近の流れが出口径 $D$, テーパー角 $\alpha$, 並びにランド長 $L$ に大きく 依存するという結果が得られた。

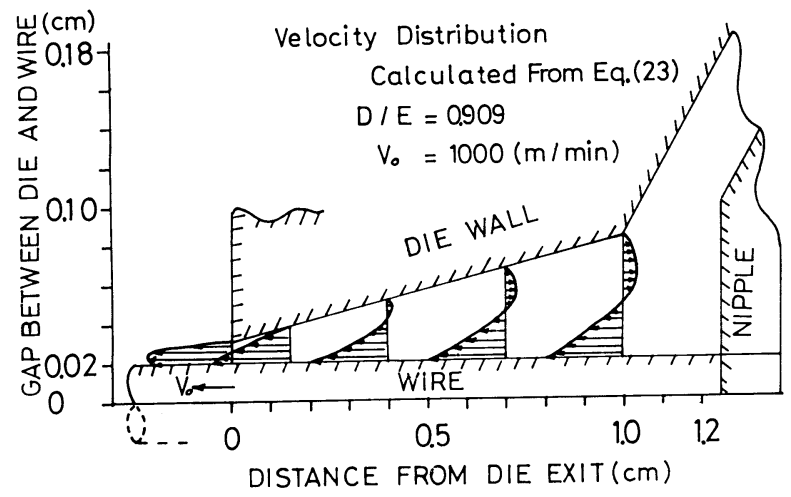

Fig. 9. Calculated axial velocity profiles in 3-deg. convergent channel between die and wire.

\section{$4 \cdot 2$ 引落率と速度分布}

ダイス部の出口径 $D$ と被覆された後の絶縁体径 $E$ の比で定義さ れる引落率 $D / E$ が押出特性に大きく影響することは，これまで の押出実験でよく経験している。この $D / E$ 比の押出特性に及ぼ 寸影響を類推するために, 引落率 $D / E$ と速度分布との関係を検 討した. Fig. 8 に $D>E$ なる引き落としをかけた場合と, Fig. 9 に示した $D<E$ の場合とでは, ダイランド部における速度分布 の計算結果は異なっている。すなわち, Fig. 8 亿示したよ5に, $D>E$ の引き落としをかける場合には，ワイヤーの移動によって
生じる星引流が圧力流よりも大きくなり，ダイス内の流れ方向の 各位置に抢ける最大流速は常にワイヤ一上で起こる。したがって， 速度分布のプロフィールもワイヤー上で最大值をとり，ダイス壁 面に向って減少していく形をとり，その減少の仕方が，流れ方向 に対して，凸形になるか凹形になるかは， $D / E$ 比，並びに $\alpha, L$ によって決定される。これに対し, 被覆される絶縁外径よりも口 径の狭い $D<E$ のダイスを用いて押し出しを行う場合には, Fig. 9 に示すように, ダイス出口径が絞られていることにより圧力流 が著しく増大し, その結果として, ワイヤーの走行速度よりも大 さい速度で流れる流動域が，ダイス出口部付近に発生することが 示された。

\section{$4 \cdot 3$ 肌荒れ現象に及ぼす引落率の影響}

純圧力流動を成す毛細管流れに招いては，ある一定のずり速度 以上で, 被押出物の表面に波を打ったような Shark Skin と呼ば れる肌荒れ現象が発生する.この現象の発生機構は複雑であり, 未 だ十分な説明が成されていないが7),8), 電線被覆押出に执いても, 押し出された表面に，先の不安定流動と類似した一連の不規則な 山と谷をもつ荒れた押出面が観察される。そしてこれまでの経験 によれば, 絶縁押出に扣いて発生する肌荒れ現象に関して,同一材 料を温度, 線速, 並びに他の種々の操作条件を同一として，ダイス 部出口径抒よびダイランド部入口部径以外のすべての寸法形状を 同じくしたダイ、ニップルを用いて押し出しを行う場合には, $D / E$ 比の值が大きいほど——言い換えれば，引落率を大きくすればす るほど——外観の荒れは防止できる(ただし，これは発泡絶縁被覆 押し出しの場合には必ずしもあてはまらない。これは発泡現象と いら要因が押出特性に大きく影響するためであり，ここでは充実 絶縁線の押し出しに話を限定しなければならない)。、いま, $D>E$ となるような引き落としをかけた状態では，先にも述べたように， 流れは率引流の支配となる。しかしながら，引落率を大きくすれ ばなぜ肌荒れが防止できるかは明らかではない，先の $D>E$ の 場合 (Fig. 8) の流れと， $D<E$ の場合 (Fig. 9) の流れに括ける ずり速度の相違を，Fig. 10 と示した。これより明らかなように，

\section{Calculated Shear Rate On Wire And} Die Wall From Eq.(25)

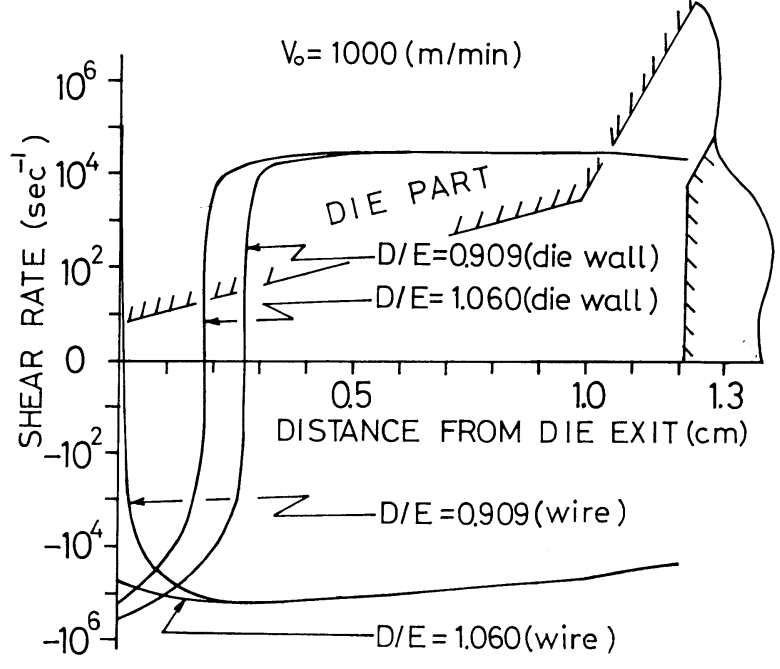

Fig. 10. Calculated variations of shear rate $\dot{\gamma}$ on die wall and wire surface with reduction ratio $D / E$. 
ダイスの出口付近に拈けるずり速度は， $D>E$ の引き落としをか けた場合の方が小さく，D/E の值が大きくなるほどずり速度は 小さくなる．ところで，純圧力流動下に沏いて発生する脈動等の 不安定流動に执いては，ずり速度が重要な要因であり，このずり 速度が小さいほど不安定流動は発生しにくい。したがって, 圧力 流動下に括いて発生する不安定流動に対して適用されるメジャ一 をもって, この電線被覆押出に抏いて発生する肌荒れ現象を考察 すれば， $D>E$ なる引き落としをかけた方が，ダイス出口部付近 に和ける壁面上でのずり速度が小さくなることより，肌荒れは防 止しやすいであろう。しかしながら，これですべてが説明される 訳ではない，压力流動下に拈ける不安定流動が，103 $\left(\mathrm{sec}^{-1}\right)$ 程度 のずら速度で発生するのに対して, 電線被覆押出の場合には, Fig. 10 より明らかなように, ワイヤー怙よび管壁面上でのずり 速度は，104 106 $\left(\mathrm{sec}^{-1}\right)$ と高い流動であり，このオーダーがダ イス, ニップル両部の寸法形状を変化させても不変であることよ り判断すれば, 電線被覆押出に扔いて発生する肌荒れ現象は, 純 圧力流動下に拈いて発生する不安定流動現象と発生機構が異なっ ていることが予想される，このように，高剪断流動であるにもか かわらず，純圧力流動に比べて，肌荒れが起こりにくいこと，そ

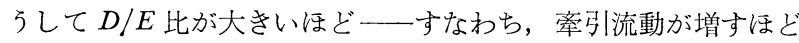
一一肌荒れが起こりにくくなる傾向にあること，更に，ダイス出 口部に执いて訫算される速度分布が， $D / E$ 比により異なること を芩え合わせると, 電線被覆押出に扣いて発生する「毫引流動」 に，これらの問題の糸口が隠されていると思われる，不安定流動 に及ぼす牽引流動の影響は，今後更に論議されねばならない。

\section{$4 \cdot 4$ クロスヘッドダイ内で発生する張力}

\section{4・4・1 引落率と張力}

ダイヘッド内で発生する張力 (Back Tension) は, フローパタ 一ンに大きく依存する。すなわち，Fig. 8 亿示した $D>E$ なる 引き落としをかける場合には，前述の上うに，ダイス内の各位置 に抢ける最大流速がいずれもワイヤ一上で最大となり，それ故， ワイヤーが樹脂を率引することになり，最大張力発生点はダイス 出口部となる。この結果を Fig. 11 に示した。 これに対して,

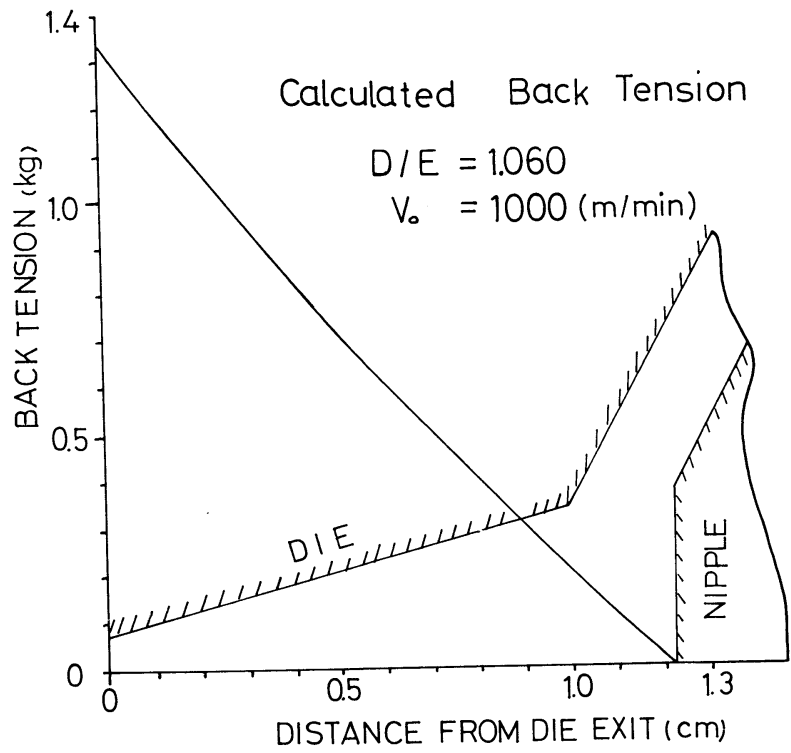

Fig. 11. Calculated tension exerted on wire.

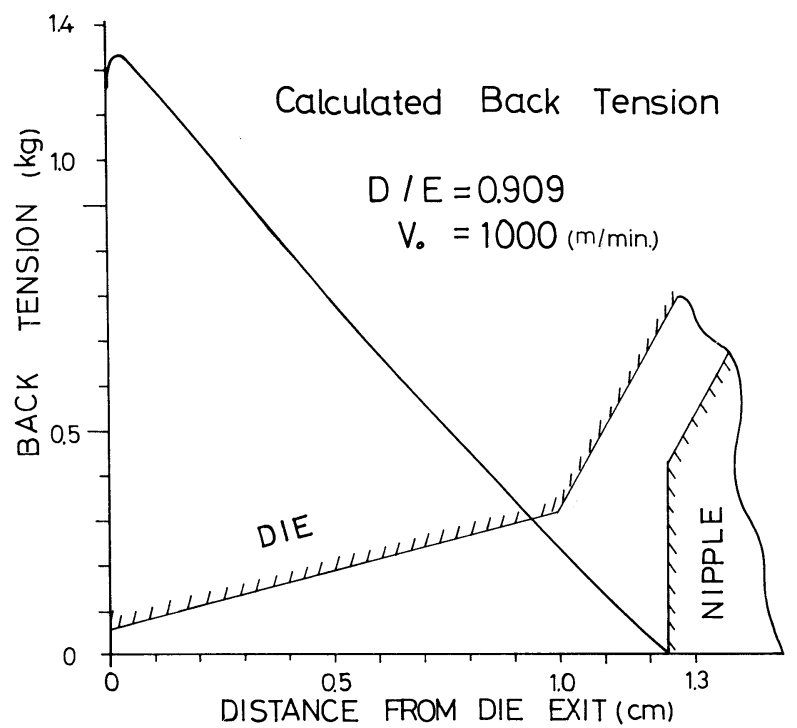

Fig. 12. Calculated tension exerted on wire.

Fig. 9 に示した $D<E$ の操作条件で押出被覆を行う場合には, ニップル側に寄った位置では, $D>E$ の場合と同様に, 最大流速 点はワイヤー上にあるが，ダイスの出口部付近においては，ワイ ヤ一の走行速度よりも大きい速度領域が存在する，この場合，そ のような位置に扔いては, ワイヤーにかかる張力は負の值（たた し，符昂はワイヤーを引き伸ばす方向に張力が働く場合を正とす る）となり，ダイス出口よりもニップル側に寄った位置で張力は 最大となる。この計算結果は，前記 Riekkinen らの報告2)におい て，同一外径の絶縁線を押し出すのに，押出圧を高めた方が発生 する張力を低く括さえることができるとする実験結果と一致する。 その訓算結果をFig. 12 に示した。

$\mathbf{4} \cdot \mathbf{4} \cdot 2$ 張力の発生と非ニュートン性

溶融高分子の非ニュートン性は，一般的にはべき指数 $n$ で評価 することができると言われている，この $n$ 值を大きく変化させる ことは，樹脂製造工程上困難であり，ポリエチレンの場合には 0.4 前後である。したがって，ここでは $n$ 值の張力発生に及ぼす 傾向を知る目的で, $n=1$ (二ュートン流体) の場合と, $n=0.1$ の

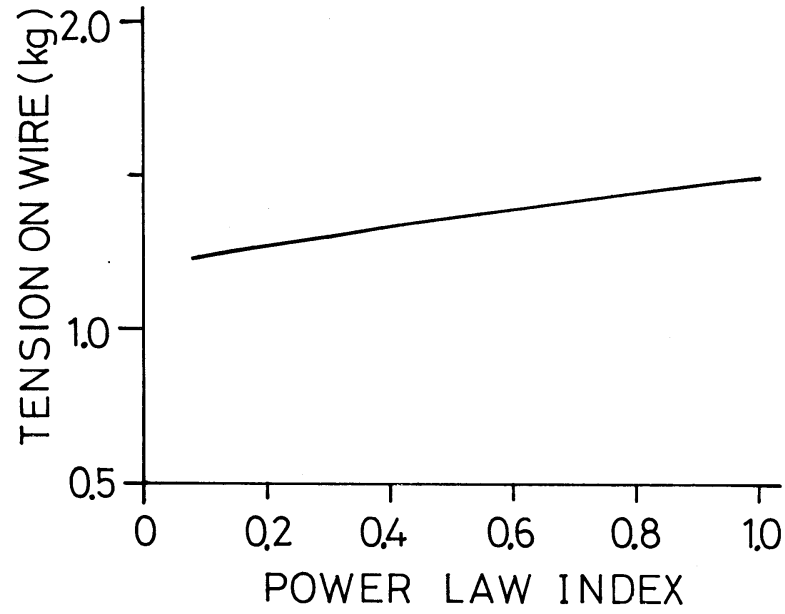

Fig. 13. Effect of the power law index $n$ on the tension exerted on wire. Parameters in eq. (28): $D / E=1.060$, and $V_{0}=1,000 \mathrm{~m} / \mathrm{min}$. 
非ニュートン性が非常に高いと思われる場合, 更飞 Table 1 の $n=0.4$ の実際的な場合の三つについて計算した。 その結果を Fig. 13 に示す.これより明らかなように，樹脂の持つべき指数 值は，張力の発生には顕著な影響を与えないことが分かる。また， 式(28)より容易に類推されるように，もら一つの非ニュートン性を 与える物質パラメーターKは張力の発生には重要であり， $K$ 值の 小さな流動性の良い樹脂を用いることが好ましい。

\section{$4 \cdot 4 \cdot 3$ 絶縁被覆押出しの低張力化について}

いま，式(28)からも明らかなように，クロスヘッド内で発生す る張力に拈よぼす要因は, Die〜Wire 間隙部長さ $L+l-L^{\prime}$, 使 用樹脂のずり応力 $\tau_{\mathrm{w}}$ ，拉よびワイヤー速度 $V_{0}$ である。このうち， ワイヤーの線速に対しては, $V_{0}{ }^{n}$ で $n=0.4$ 程度であることより, 発生する張力には, 線速乞のものは大きく影響しないと考兄られ る。また，ワイヤーに作用するずり応力 $\tau_{\mathrm{w}}$ の影響を小さくする ためには，先にも述べたように，非ニュートン流体の物質パラメ 一ターKの小さな樹脂を選定する必要がある。乙かしながら， Die〜Wire 間隙部の長さ $L+l-L^{\prime}$ の影響は非常に大きい。特に, ダイランド部の長さ $L$ の影響は重要であり, 張力軽減のためには Lを小さくする必要がある。すなわち，これまでの考察によりク ロスヘッド内で発生する張力を軽減させるためには，(1) $K$ 值の 小さい樹脂の選択，(2) Die〜Wire 間吵部の長さ——特にダイラ ンド部 $L$ 一を短くする，(3) 䋭引流動を叔さえ, 压力流動を增 大させる（このためには，D/E 比を小さくする)，などの処置を とることが重要である．ただし，(2) 項抒よび (3) 項にあげた内容 は，いずれも先の肌荒れ現象を発生させやすい内容であり，実際 には張力並びに肌荒れ両特性を中心に，最適形状を持つダイスの 設計が必要となる。このためには，ダイランド部のテーパー角 $\alpha$ を検討することが一つの方法である．Fig. 14 に，テーパー角 $\alpha$ と発生する張力 $T$ の関係を示した.

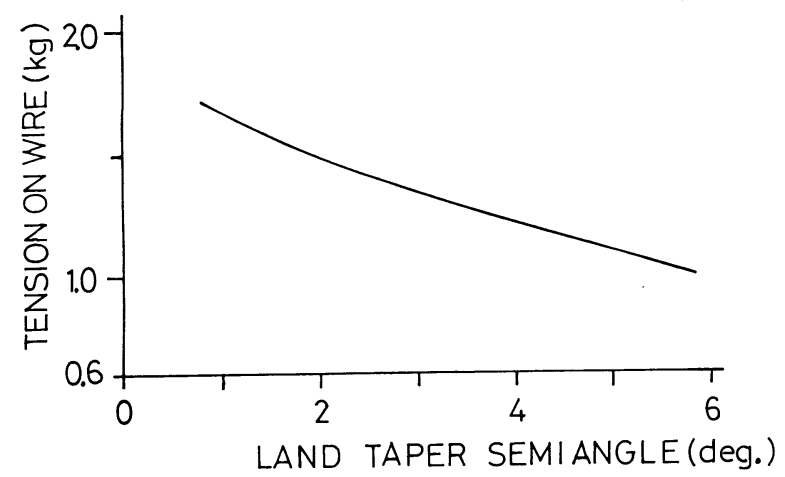

Fig. 14. Calculated tension exerted on wire as function of semi-angles of die land. Parameters in eq. (28): $D / E=1.060, V_{0}=1,000 \mathrm{~m} / \mathrm{min}$, and $n=0.4$.

\section{$4 \cdot 5$ 今後への問題点}

本解析に扣いては，高速絶縁押出に適したダイヘッド部の設計 を行らための第一段階として，ダイヘッド部を流れる流体の速度 分布を求め，ダイヘッド内での樹脂の流れを推定することにより， 肌荒れ現象防止への一つの考察を加光た．更に，ダイス内を走行 するワイヤーに発生する張力を表示する記述式を誘導し，実際の 操作条件下での張力の発生を推定する方法を提起した。しかしな がら，ワイヤーコーティング用のダイヘッド内の樹脂流動を明ら
かにするためには, 速度分布, 張力以外に, 圧力分布並びに運動方 程式の解としての流量を求めねばならない。このうち, 压力分布 は式(22)を流路に沼って積分すれば求められるが，積分にあたっ ては, 流路出口部および入口部での境界条件の設定に問題がある. すなわち，Die〜Wire 間隙部に対しては，満足させるべき流路 入口部での境界条件が不明であること，更に，Die〜Nipple 間吵 部内に関しても境界条件が未知であり, 式(22)を解くことは, は なはだ困難である。また，本解析においては，流れを互いに独立。 した二つの領域に分けて考鼻るという便法を用いたが，両領域の 境界面に打ける領域の接合を吟味することが必要かつ重要である. この接合をどのような評価関数で与えるかについては, 今のとこ ろ有効な手段を持ち得ていないが，この接合がうまく評価できれ ば, 二つの領域内を流れる樹脂の流動に関して, 相互に及ぼし合 う流れへの影響をも含めた流れの表示式が提示できるものと思わ れ, 圧力分布, 吐出量の表示式の誘導と合わせて, より厳密な研 究検討が望まれる。

\section{5. 結}

論

電線被覆押出用のクロスヘッドダイ内に拈ける樹脂流動のうち 速度分布を記述する表示式，並びにダイス内をワイヤーが走行す ることによりワイヤー上に発生する張力に関する記述式を誘導し， 数値解析を行った，解析では，非平行な同心テーパー状の二重円 筒管内の流れに対して，これを流れ方向に微細等分化し，分割さ れた微小流路の流れを二枚の平行平板間の流れとして，指数流体 の定常，非圧縮性，等温流れを仮定した。得られた関係式，扣上 び数值計算の結果より，ダイヘッド内を流れる流体の速度分布， 並びに流れに及ぼす流路形状の影響，更に発生する張力に関する 推定を行った。 ここに提起した解析方法は，平行平板流れとして 取り报ったことによる幾つかの問題点もあり，現実の電線被覆押 出工程に和ける種々の問題点のうちの一部の現象しか説明するこ とができない限定法である。しかしながら, ワイヤーコーティン グ用のクロスヘッドダイ内を流れる溶融蛣脂の流動性を推定すべ き実用的な関係式がないと言ってもよい現状からみて，その実用 的意味は大きいものと考学る。

謝辞 本研究遂行にあたり，有益な助言ならびに教示下された 京都大学倉田道夫教授, ならびに本解析に熱心に協力された古河 電気工業株式会社松永隆, 望月肇, 島野隆各氏に深謝いたします。 また，本研究の発表を許可された古河電気工業株式会社に感謝し ます。（昭和51年10月29日 第24回レオロジ一討論会にて講演）

\section{引用 文 献}

1) Rokunohe, M., Y. Ueno, J. Konishi, and M. Okada, 24th. I.W.C.S. Proceedings, 53 (1975).

2) Riekkinen, A. and R. Ekholm, ibid., 43 (1975).

3) Oka, S., J. Phys. Soc. Japan, 19, 1481 (1964).

4）伊藤公正，プラスチックス， 24，89 (1973).

5) Fenner, R.T., Trans. J. Plastics Inst., 35, 701 (1967).

6）林田建世, 高分子化学, 18, No. 190, 99 (1961).

7) J.P. Tordella, "Rheology" Chap. 2 (1969) Academic Press Inc., New York.

8）大柳康, 山口章三郎, 日本レオロジ一学会, 第 3 年会講演 予稿集, 5 (1976), 